日本学術会議と日本科学技術ジャーナリスト会 議が共同主催したシンポジウム「科学と社会一い ま科学者とジャーナリストが問われている」が 2002年11月13日、日本学術会議講堂で開かれ、私 はジャーナリスト側を代表するパネリストの一人 として参加した。

21 世紀を迎え、科学技術がますます重要になっ てきて打り、さまざまな科学情報が社会にあふれ ているが、その一方で日本は正しい科学情報の普 及が先進国の中で最も遅れているという指摘もあ る。もし、そうだとしたら、その責任は科学者に あるのか、それともジャーナリストにあるのか。 そんな問題意識から雨会議が共催で開くことにな ったシンポジウムである。

\section{科学報道元年は 1957年}

私はまず、冒頭の発言で、戦後の日本における 科学ジャーナリズムの歴史を要約して述べた。日 本の新聞社や放送局に「科学部」といった専門記 者の組織が生まれたのは、1957年前後で、その年 を私は「科学報道元年」と呼んでいること。それ は同年に国際地球観測年 (IGY)が始まって1月に南 極の昭和基地が生まれ、8月に東海村の日本原子力 研究所の第1号原子炉か臨界になり、10月にソ連の スプートニク 1 号が打ち上げられるなど、大きな科 学ニュースが続いたからである。
その後、原子力と宇宙開発を両輪として、科学 報道は拡大の一途をたどり、報道全体の中で占め る比重もどんどん大きくなっていった。しかし、 $50 、 60$ 年代は、国中が科学技術にバラ色の夢を描 いていた時代で、科学報道もその中身はといえば、 もっぱら難しい科学をやさしく説明する「解説」 の時代だった。

しかし、やさしく解説するだけではジャーナリ ズムとはいえない。その事柄について批判の目が 加わってこそ、初めてジャーナリズムといえるわ けである。では、科学技術に関して批判の目が生 まれてきたのはいつか。それは、公害・環境問題 に対する関心が爆発的に広がった70年代からだと いっていい。

つまり、日本が敗戦からしだいに復興し経済成 長を遂げていく中で、科学技術は常に経済発展の 原動力であり、豊かな生活を生み出す源泉であっ た。そのため、50、60年代では、日々豊かになっ ていく経済発展に目を奪われて、その㓌で密かに 進んでいた公害や環境破壊には、目が向かなかっ たのである。

\section{科学への批判は70年代から}

70 年代に入って、公害・環境問題の深刻化で、 科学技術は必ずしも経済発展の源泉ではなく、時 には環境破壊の元冈にもなることを人々は実感し 
た。そこで初めて「科学技術は人間を幸せにする とは限らない」ことに気づいたのである。

そう見てくると、批判の目をもった科学ジャー ナリズムが生まれてから、まだ 30 年余しか経って いないことになる。この歴史の浅さと、その間の 科学技術の発展があまりにも急速だったため、科 学ジャーナリズムの足跡は、必ずしもまっすぐな 道を歩んできたとは言いがたい。時に行きすぎた り、ためらったり、価值判断を誤ったりと、ジグ ザグなコースをたどってきたといえよう。

しかも、本来なら、その報道の一つひとつを検 証し、そこから教訓を汲及取って次の報道に生か していくべきなのだが、次々と新たなニュースが 起こってくるため、その対応に追われて検証の余 裕がなく、同じような誤りを繰り返している状況 である。

そういう反省のうえにたって、ジャーナリスト の側から科学者に詨して三つのことを要望したい、 と私は次の三点を挙げて冒頭発言を締めくくった。 第一に、科学者は自分の研究内容を社会に対して 明らかにする「説明責任」があること。第二に、 自分の研究を含めて常に冷静かつ客観的な評価を 下すこと。第三に、科学ジャーナリズムに対して も厳しい批判の目を向けること、である。

\section{水俣病では原因究明を遅らす}

次に、シンポジウムの討論の中で、私が最も力 をいれて問題提起したのは、「科学者の責任はなぜ 問わ机ないか」というテーマである。「水俣病」 「心臓移植」「地震予知」の三つの具体的な例を挙 げて、「ジャーナリズムにも問題があったが、科学 者の言動によって重大な結果を招いた。その責任 がなぜか問われていない」ことを指摘したのであ る。
水俣病は、1956年に「奇病の多発」が報告され、 熊本大学医学部が総力を挙げて原因の究明にあた った結果、59年には「工場廃水による有機水銀が 原因」と突き止められた。それを受けて、厚生省 の食品衛生調査会が「魚介類を通じて摂取された 有機水銀による食中毒」と答申し、本来なら、こ こで工場廃水の規制と被害者の救済に乗り出せた はずなのである。

ところが、企業側の依頼を受けたと思われる東 京工大教授や東邦医大教授らが「非水銀説」を唱 え、それに通産省が加担して、食品衛生調査会の 答申をうやむやにしてしまった。原因をめぐって 学界が対立しているという状況を作り出して、原 因の確定を遅らせ、その間に企業側は患者たちと 見舞金協定を結んで、一件落着の形にしたのであ る。

この協定は、「将来、工場廃水が原因だとわかっ た場合でも、新たな要求はしない」という誓約書 を交わして、僅かな見舞金を贈るというものだっ た。しかも、企業側は、この時すでに、工場廃水 をえさに混ぜて与えたネコが水俣病の症状を呈し た実験で、本当の原因を知っていたにもかかわら ず、それをひた隠しにして落着を図ったのである。

こうして原因の確定はずるずると引き延ばされ、 政府が公害病と認定したのは、なんと68年のこと である。奇病多発から 12 年後、熊大による原因究 明からでも9年の歳月が流れたのだ。その間にどれ ほど患者を増やし、被害を拡大したことか。その 罪の重さは計り知れないものがある。

もちろん、その間のジャーナリズムの責任も大 きかった。十分な取材も尽くさずに、ただ「報道 の中立」を守らうとして、「水銀説と非水銀説をめ ぐって学界が対立」と報じてきたのである。その 責任も厳しく問われなければならないが、原因の 
確定を遅らせるために意図的に詨立をつくりだし た科学者や、ネコの実験をひた隠しにしていた科 学者らの責任は、問われなくてよいのだろうか。

\section{暴走だった和田・心臓移植}

68年の札幌医大、和田寿郎教授による心臓移植 も、大暴走だったにもかかわらず、日本の医学界 はきちんと総括せず、和田教授の責任も問われて いないのだ。

日本で最初の心臓移植が和田教授の手で行われ たのは、南アフリカのクリス・バーナード博士が 世界で最初の心臟移植を行ってから約10力月後の ことだった。移植を受けた18歳の青年は、83日間 生きて亡くなったが、この移植に最初に疑問の声 をあげたのは、同じ札幌医大の内科の教授だった。

「移植を受けた患者は、心臟を取り替えなければ ならないほど、心蔵は悪くなかった」と医学誌に 発表したのである。弁の一つが悪かっただけで、 それを人工弁に替えてほしいと外科に送ったとい うのだ。実際に患者を診ていた内科医の告発だけ に衝撃は大きかった。

和田教授は、患者の心臓は三つの弁とも悪く、 移植以外に助かる方法はないと言っていたのだか ら、大違いである。そして、病理解剖を行った病 理学の教授も、内科の教授の言い分に軍配を上げ たのだ。

心臟を提供したドナーの死にも、重大な疑惑が あった。小樽の海で溺れた学生が、病院で手当て を受けて息を吹き返し、「もう大丈夫」と治療した 医師も帰宅した。そのあと、急変したとして院長 が札幌医大に転送したのだが、その院長は和田教 授の友人で、かねてから「ドナーがいたら」と依 頼されていたことも明らかになったのである。

ドナーの両親が病院に駆けつけた時にはすでに
胸部が開かれていたこと、死亡時刻より前に大量 の輸血用血液が発注されていたこと、脳死の判定 に欠かせない脳波の記録もなかったこと、などの 不可解な事実もあった。

これほどの疑問があったにもかかわらず、札幌 地検は「証拠不十分」で不起訴処分にした。恐ら く司法が医学に介入することを避けたのだろう。 ところが、この地検の不起訴処分を受けて、医学 界まで和田移植の総括をせず、和田教授の責任も うやむやにしてしまったのである。

医師に対する信頼感がなければ実施できない心 臓移植は、このため、日本では31年間も全く行わ れず、移植医療は世界の大勢から大幅に遅れてし まったのだ。

\section{「幻覚」振りまく地震予知}

地震予知の問題で問われるべき科学者の責任は、 水俣病や心臟移植とは全く違う。科学者の具体的 な行動によって被害を広げた「過去」の責任では なく、まだ起こっていない「未来」に対する責任 ともいうべきものだ。

駿河湾を震源とするマグニチュード8級の東海地 震が近く起こるだろうということで、世界で初め ての地震予知体制が発足したのは、78年のことで ある。この大地震に備えて観測網を整備し、異常 が観測されたら判定会が召集されて、首相が警戒 宣言を発するという仕組みである。

大規模地震対策特別措置法と呼ばれるこの法律 は、「地震予知がもしできたら」という仮定に基づ いて制定された法律だった。ところが、制定され るやいなや、地震予知はできる」という前提で生 まれたような形になり、東海地震の起こる前には 必ず警戒宣言が出るかのような錯覚が社会に広が ってしまったのである。 
岩石の破壊という地震現象の特殊性から、予知 はそう簡単にはできないことを地震学者は知って いるにもかかわらず、社会に広がった錯覚を正そ うとはしなかった。阪神大震災が「ある日、突然」 に起こり、大震法の扔かしなところを直す絶好の 機会だったのに、それも見送ってしまったのだ。

「地震予知がもしできたら」その対応策を考えて おくことは結構なことだが、「予知に頼る防災」は 明らかに誤りだ。大震法が施行されて、地震予知 に多額の研究費が出るようになったため、いまさ ら「予知はできない」と言い難くなったのかもし れないが、それを社会にきちんと言うことが科学 者の責任というものだろう。

\section{科学者も相互批判を}

以上、三つの具体的な例を挙げて「科学者の責 任はなぜ問われないのか」という問題提起をした
わけだが、シンポジウムでは残念ながら論議は深 まらなかった。科学者に限らず、自分の専門外の ことに口を出すことを憚る空気があり、まして科 学の専門分野がますます細分化されてきたため、 分野を超えて発言することが難しい状況が生まれ ている。

しかし、社会の中に占める科学技術の比重がこ れほど大きくなってきた今日、科学者の相互批判 がしにくいような空気が広がっていたら、科学技 術の健全な発展は望めないだろう。

まったく同じことが、科学ジャーナリズムにつ いてもいえる。科学ジャーナリズムの場合は、と くに科学者からの㛜しい批判がないと、健全な発 展は望めない。

科学者と科学ジャーナリストの相互批判の場と して、今回のシンポジウムは、ささやかな一歩を 踏み出したといっていいだろう。

\section{日本学術協力財団の出版図書 \\ 「今、動物学がおもしろい〜宇宙と地球生物〜」 \\ 頒価2,000円}

宇宙と地球生命

毛利 衛（宇宙開発事業団有人宇宙活動 推進室長)

○向井さんのお伴をしたメダカたち 井尻 憲一 (東京大学助教授)

宇宙での動物の生殖と発生

浅島 誠（東京大学教授）

山下 雅道（東京大学教授）

小池 元 (東京大学大学院)

動物の行動と重力

最上 善広 (お茶の水大学助教授)
○細胞はどのようにして重力を感じるか 佐藤 温重 (東京医科㐘科大学教授)

植物はどのように重力を感じるか 増田 芳雄 (帝塚山短期大学教授) 保尊 隆亨 (大阪市立大学助教授)

宇宙環境と人間—宇宙医学の現状— 渡邊 悟（藤田保健衛生大学教授）

宇宙環境でのライフサイエンス 長岡 俊冶（宇宙開発事業団宇宙環境利用 システム本部主任開発部員） 